\title{
COMPENSATION FOR PERSONAL INJURY IN NEW ZEALAND ITS RISE AND FALL BY IAN CAMPBELL
}

\author{
Auckland University Press, Auckland, 1996, $286+x$ pages. Price $\$ 39.95$
}

\section{Reviewed by WR Atkin*}

The Woodhouse Report on accident injuries ${ }^{1}$ was released in December 1967. I began studying law the following year and not surprisingly the Report was one of the features of the first year course. I recall reading the Report eagerly, being impressed by its clarity and vision. Perhaps nothing stimulated this tentative first year student more and whetted his appetite for what was to come. As we look back 30 years later, can there be any doubt that the Report stands as a giant beacon in the development of policy in this country. It is a classic document, nationally and internationally, little excelled by anything else written since.

The scope and radical nature of the Report took some by surprise, on both the left and right of the political spectrum, from trade unions to insurance companies and business. It proposed sweeping away the myriad of mechanisms for compensating injuries, including the right to sue at common law, and replacing them with a unified comprehensive scheme. Eventually, after further examination, the National Government of the day agreed to a new accident compensation law. The Labour Government which was elected shortly afterwards extended it to non-earners who were not included in the National legislation. Thus, it can be said that accident compensation was originally developed in a largely nonpartisan way and was greeted positively. "In the early days of the ACC the morale of staff was very high, as they considered themselves privileged to be taking part in such an innovative experiment." 2

Today, accident compensation has sadly become a political football. The Right urges competition and privatisation, though interestingly not a return to the common law, probably because of a realisation that Woodhouse was correct in assessing the old system as being costly and unfair. The Left urges higher benefits and extension of the scheme to

* Reader in Law, Victoria University of Wellington.

1 Report of the Royal Commission of Inquiry Compensation for Personal Injury in New Zealand (Government Printer, Wellington, 1967) commonly referred to as the "Woodhouse Report" after the name of the chairperson.

2 P 48 of the book under review. 
cover all forms of incapacity, with the occasional voice suggesting that workers ought to be able again to sue their employers for damages. In 1992, the Right won a partial victory when the new Accident Rehabilitation and Compensation Insurance Act cut benefits, narrowed the scope of the scheme and made the funding system more favourable to employers.

In this environment, it is timely that a new book should be produced on the history of accident compensation and the competing arguments for future change. Someone who has long been involved in the process from the workers compensation days is surely an ideal person to write such a book. Ian Campbell was secretary and chief executive of the Workers' Compensation Board for 22 years and Director of Safety of ACC until 1981. His book gives an overview of the approached to compensation from the earliest days, but concentrates on the more recent changes to ACC and the forces at work behind these changes. He does not pretend to be anything he is not. This is not for example a legal text and while discussions of case law and statute are found within its pages, lawyers will not find the detailed analysis they usually strive for. In many ways, this is one man's journey, a life tied so intimately to a major area of social policy. He is therefore passionate. He expresses his views without equivocation. Broadly speaking, he favours Woodhouse and has scant respect for the 1992 Act.

He no doubt considers that the pendulum has swung away from prevention of accidents, compensation and rehabilitation towards the interests of employers and business. Towards the end, he asks what he describes as "the principal question": "Whose interests should be paramount? Should it be the injured and the dependants of those killed, or the providers of the funds?"3 While he says that "[t]his is not a black-and-white issue but rather a matter of the weighting given to respective views", the whole tenor of the book is that the injured have tended to be forgotten. He says of the 1992 Act that many of the changes "reflect a parsimonious attitude which clearly belies the basic premise upon which the whole accident compensation scheme was founded"4 and "[i]t would be difficult to conceive a more savage attack on a compensation system which, though not perfect, was serving many well". 5 In fact he can conceive a more savage attack, namely privatisation,

$3 \quad$ Pp 252-253.

$4 \quad$ P 253.

5 P 138. 
which, although not indexed, is examined in several places. Referring to a ministerial working party which preceded the 1992 Act, he says that: ${ }^{6}$

[the working party] put great effort into finding a solution so that the private insurers might again be permitted to undertake compensation insurance business. One thing is certain: such a move will bring no benefit to the claimant. Concentration on this aspect of the exercise left the working party no possibility of giving attention to the important subject of prevention.

And again: ${ }^{7}$

The continuing pressure from employer organisations for accident compensation to be privatised needs to be viewed in the light of the probable developments that would accompany such a move. The multiplicity of operators would mean that administrative expenses would increase substantially, and here we have the past experience of the workers' compensation to guide us. This would lead either to an increase in premiums or a reduction in compensation, or probably both.

One of the 1992 changes which is of interest to lawyers is the removal of mental injury (unless the result of physical injury) from the scope of the Act. This is described as "[p]ossibly the most ominous feature of the legislation". 8 From a logical point of view, the justification for the change is hard to find, but it was no doubt a politically pragmatic way of cutting down the apparent broadening of the situations which the courts had held came within the ambit of the Act. ${ }^{9}$ But from a policy point of view, Campbell queries the wisdom of the new law: ${ }^{10}$

There can be no doubt that today's working environment is much more stressful than was ever the case since we left the very demanding workplaces of the previous two centuries behind us. Furthermore, some of this stress has been caused by government policies in the past decade, which have made jobs not only much less secure but often far more demanding.

Another matter of interest is what Campbell refers to as "the re-emergence of common law actions". ${ }^{11}$ This comes about partly through the Act's reduced cover and partly from the sense that the benefits under the Act are now often inadequate. In referring to the

\footnotetext{
6 P 86. See also $\mathrm{p} 83$.

$7 \quad \mathrm{P} 138$.

$8 \quad \mathrm{P} 137$.

9 EG ACC $v E$ [1992] 2 NZLR 426 (nervous breakdown as a consequence of a management training course).

10 P 111.

$11 \quad \mathrm{P} 133$.
} 
exemplary damages, Campbell probably makes an understatement when he says that the extent of such damages "remains to be determined but if unlikely to be great"12 and is also perhaps less sanguine than he might be about the effect of the Health and Safety in Employment Act 1992, which, in terms of accident prevention, ought to be seen as a significant companion piece to the 1992 accident compensation legislation.

The book is marred by one or two presentation errors. For example, on $\mathrm{p} 23$ there is a cross-reference to comments of "H Poland MP referred to on $\mathrm{p} 23$ " when they in fact appear on p 20. On p 70 reference is made to "1994-1887 Strategic Directions" which if correct casts a new light $f$ strategising. In some places statements are made without full explanation, citation or referencing. An example is at $\mathrm{p} 61$ where a judgement of Barker $\mathrm{J}$ is left uncited. Again an article by Peterson is referred to on pp 63 and 64 but the footnotes bear little relation to the article. At the top of $p 98$, two cases are cited without explanation and to the uninitiated may appear a complete mystery. Similarly on $\mathrm{p} 104$ a provision in the definition of "accident" is mentioned as having "caused considerable concern" but we are not introduced to what this concern is. These are matters which should have been remedied by a diligent publisher. It is likewise normally the publisher's responsibility to prepare the Table of Cases (the book surprisingly has no Table of Statutes) and it is disappointing that the Table contains so many mistakes which are not apparent in the text itself. One example will suffice. Charles Burrell \& Sons Ltd $v$ Selvage is cited at [1921] 50 LIKB 1340 at p 107 of the text. It should be (1921) 90 LJKB 1340 at p 106 of the text. Two other complaints often made by reviewers can be repeated: the table of contents contains chapter headings only, whereas in a book like this the inclusion of the many subheadings would have been helpful; and the collection of all the footnotes at the end of the book (rather than on each page or at the end of each chapter) simply makes the reader's life a misery. Finally, a book like this merits a bibliography: Appendix 5 contains "Recent Articles on Various Aspects of the Accident Rehabilitation and Compensation Insurance Act" but this is inadequate and in any event omits one of the most trenchant articles, Ison's "Changes to the Accident Compensation Scheme: An International Perspective". ${ }^{13}$

The subtitle of the book refers to accident compensation's rise and fall. This may be too pessimistic a picture. For many new Zealanders the system works well. However the book adds weight to the concern that accident compensation is under attack. With its grounding in the history of compensation mechanisms, the book represents a valuable addition to the debate about future directions.

12 P 135.

13 (1993) 23 VUWLR 26 in footnote 41. 